\title{
Notes on the vocalizations of Grey-headed Negrofinch (Nigrita canicapillus)
}

\section{Peter Boesman}

In the following we briefly analyze and compare voice of the different races of Grey-headed Negrofinch (Nigrita canicapillus). We also try to quantify the extent of any vocal differences using the criteria proposed by Tobias et al. (2010), as a support for taxonomic review.

We have made use of sound recordings available on-line from Xeno Canto (XC) and Macaulay Library (ML).

Song is a phrase of typically three pure whistles at slightly different pitch (duration of song phrase about 2-3s, whistles typically between 3 and $4 \mathrm{kHz}$ ).

There are relatively few recordings available. An overview per race:

emiliae

Liberia
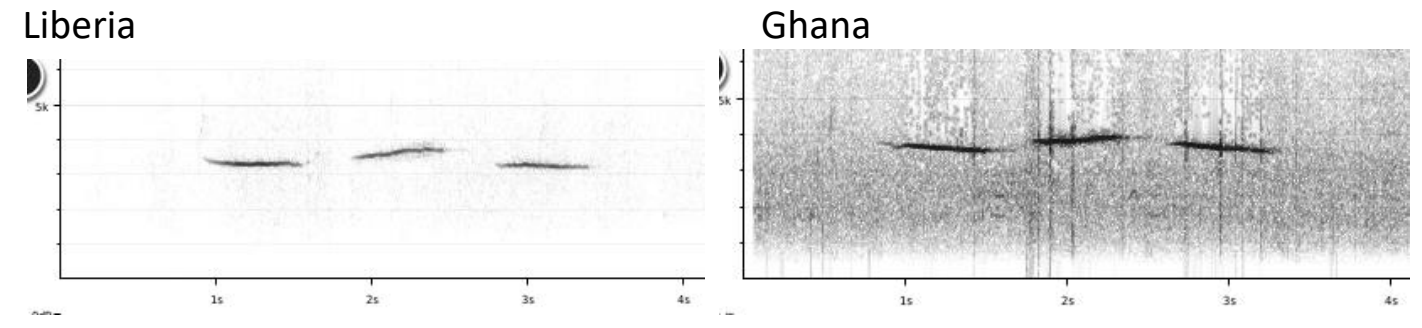

nominate

Cameroon

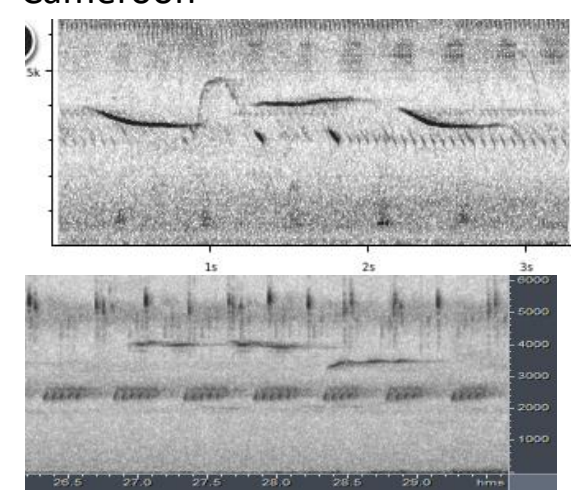

E Congo
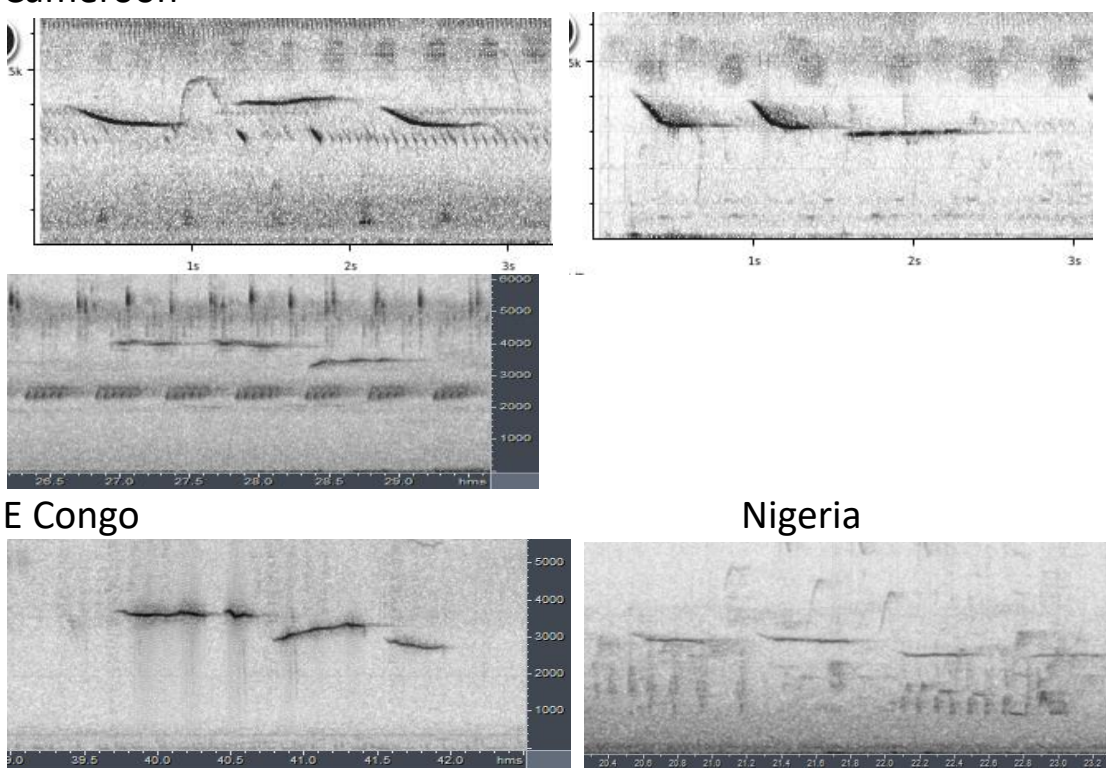

Nigeria

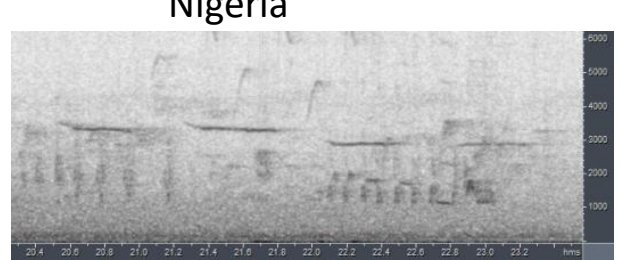

No recordings available of other races (apart from a very poor recording of schistaceus). 
Song of nominate seems to have somewhat more variation than song of emiliae, but the former race obviously also has a much larger range.

Other than that, song of both races very similar.

More recordings, especially of the other races, are needed to make a more in depth analysis.

This note was finalized on 28th April 2016, using sound recordings available on-line at that moment. We would like to thank in particular the sound recordists who placed their recordings for this species on XC and ML: Sander Bot, James Bradley, Rolf de By, Charles Hesse, Peter Kaestner, Stuart Keith, Mike Nelson, Etienne Leroy, David Moyer, Samuel Osinobi, Bram Piot, Mark Robbins and Paul Rodewald.

\section{References}

Tobias, J.A., Seddon, N., Spottiswoode, C.N., Pilgrim, J.D., Fishpool, L.D.C. \& Collar, N.J. (2010). Quantitative criteria for species delimitation. Ibis 152(4): 724-746.

\section{Recommended citation}

Boesman, P. (2016). Notes on the vocalizations of Grey-headed Negrofinch (Nigrita canicapillus). HBW Alive Ornithological Note 348. In: Handbook of the Birds of the World Alive. Lynx Edicions, Barcelona. (retrieved from http://www.hbw.com/node/1252877 on 27 October 2016). 